\title{
Chemoselective Addition of Grignard Reagents to Alkoxycarbonylalkyl- N-imidazolium-N-methyl Amides: Synthesis of 4-Oxo and Homologous Esters
}

\author{
María A. de las Heras, Juan J. Vaquero, José L. García-Navio, Julio Alvarez-Builla* \\ Departamento de Quimica Orgánica, Universidad de Alcalá, 2887 l-Alcalá de Henares, Madrid. Spain.
}

\begin{abstract}
A method for the synthesis of 4-oxo and homologous esters is achieved by metalation of alkoxycartonylalkyl-N-imidazolium-N-methyl amides with lequiv of LDA followed by highly chemoselective addition of 1 equiv of a Grignard reagent. 1997 Elsevier Science Ltd. All rights reserved.
\end{abstract}

Although it has been known for a long time that the carbonyl group can be formed by reacting organometallics with carboxylic acid derivatives, ${ }^{1}$ only with the development of selective acylating reagents ${ }^{2}$ (e.g. Weinreb's amide ${ }^{3,4}$ ) has this reaction proved to be of synthetic utility. Recently, we demonstrated that $\mathrm{N}$-imidazolium- $\mathrm{N}$ methylamides 1 and bis-amides 2 behave as highly selective acylating reagents towards organometallics leading in good to excellent yields to ketones ${ }^{5}$ and diketones. Moreover, the 1-( $N$-alkoxyoxalyl- $N$-methylamino $)-3-$ methylimidazolium salts 3 were shown to yield 2-oxo esters by addition of Grignard reagents ${ }^{7}$ whereas in the case of the equivalent Weinreb type amide 4 the addition of an aliphatic organometallic takes place on the ester group leading to undesired 2-oxo amides ${ }^{8}$ (Scheme 1).

Me<smiles>[X]C(=O)N(C)[n+]1ccn(C)c1</smiles><smiles>[X][C@H](C(=O)N(C)[n+]1ccn(C)c1)N(C)C(=O)N(C)[n+]1ccn(C)c1</smiles>

2

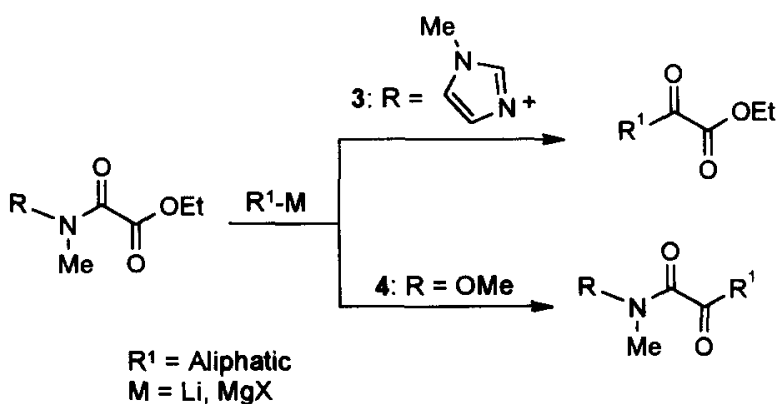

\section{Scheme 1}


This chemoselective addition to the imidazolium amide moiety encouraged us to extend the method to the preparation of other 2-oxo and homologous esters. Unfortunately, our initial attempts to apply the method to the synthesis of 3-oxo esters failed when the alkoxycarbonylmethyl imidazolium amides $5(n=1)$ were treated with 1 equiv of LDA followed by addition of 1 equiv of the Grignard reagent. In this case, the salt 5 was extensively recovered and variable mixtures of 6 and 7 were formed in low yields (7-11\%). However, here we show that in extending the above strategy to other alkoxycarbonylalkyl imidazolium amides $(n>1), 4$-oxo and homologous esters 6 can be obtained in good yields by a highly chemoselective attack of the Grignard reagent to the carbonyl of the imidazolium amide moiety.

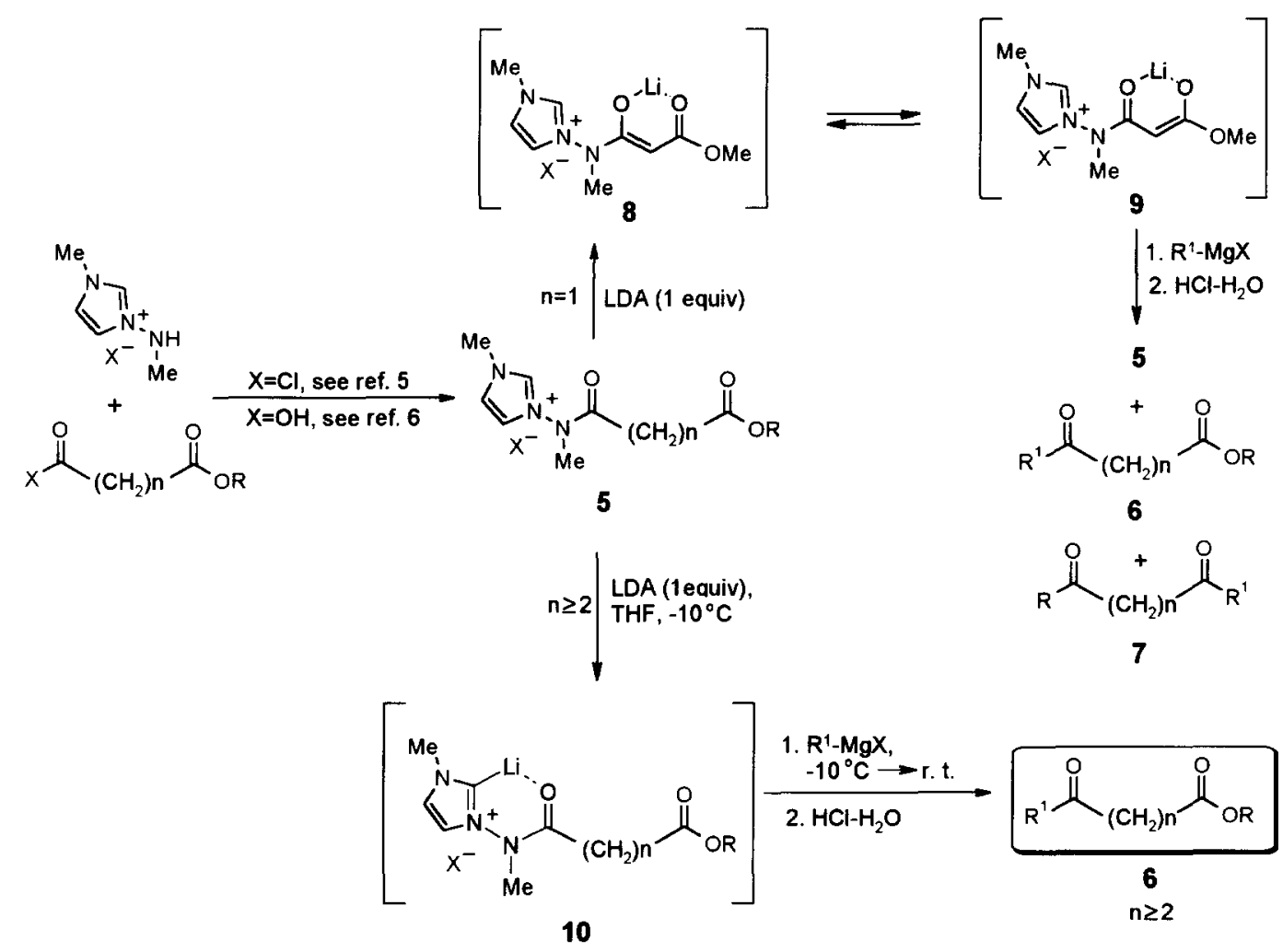

Scheme 2

The difficulty in obtaining 3-oxo esters from $5(n=1)$ is likely due to the competitive enolization of 5 in the presence of LDA (1 equiv) and concomitant generation of stable cyclic enolate complexes which precluded the attack to the amide or ester groups by the organometallic reagent. Unlike in the precedent case, upon treatment of imidazolium salts 5 ( $n \geq 2$ ) with 1 equiv of LDA the imidazolium ring is metalated at $\mathrm{C}-2$ position? with the more than likely activation of the carbonyl of the amide group towards the attack of the Grignard reagent (Scheme 2) 
Table 1. 4-Oxo and homologous esters 6 prepared by chemoselective addition of Grignard reagents to 5

\begin{tabular}{|c|c|c|c|}
\hline Compd No. & $\mathrm{R}^{1}-\mathrm{MgX}$ & Oxo Ester & Yield $(\%)$ \\
\hline 6a & $n-\mathrm{Bu}$ & $\mathrm{Me}-\left(\mathrm{CH}_{2}\right)_{3}-\mathrm{CO}-\left(\mathrm{CH}_{2}\right)_{2}-\mathrm{CO}_{2} \mathrm{Me}$ & 58 \\
\hline $\mathbf{6 b}$ & $t$-Bu & $(\mathrm{Me})_{3} \mathrm{C}-\mathrm{CO}-\left(\mathrm{CH}_{2}\right)_{2}-\mathrm{CO}_{2} \mathrm{Me}$ & 54 \\
\hline $6 c$ & 4-Me- $\mathrm{C}_{6} \mathrm{H}_{4}$ & 4-Me- $\mathrm{C}_{6} \mathrm{H}_{4}-\mathrm{CO}-\left(\mathrm{CH}_{2}\right)_{2}-\mathrm{CO}_{2} \mathrm{Me}$ & 69 \\
\hline 6d & $\mathrm{C}_{6} \mathrm{H}_{5}$ & $\mathrm{C}_{6} \mathrm{H}_{5}-\mathrm{CO}-\left(\mathrm{CH}_{2}\right)_{2}-\mathrm{CO}_{2} \mathrm{Bu}^{\mathrm{t}}$ & 73 \\
\hline $6 e$ & $\mathrm{CH}_{3} \mathrm{C}=\mathrm{C}$ & $\mathrm{Me}-\mathrm{C}=\mathrm{C}-\mathrm{CO}-\left(\mathrm{CH}_{2}\right)_{2}-\mathrm{CO}_{2} \mathrm{Me}$ & 73 \\
\hline $6 f$ & $\mathrm{CH}_{3} \mathrm{C}=\mathrm{C}$ & $\mathrm{Me}-\mathrm{C} \equiv \mathrm{C}-\mathrm{CO}-\left(\mathrm{CH}_{2}\right)_{2}-\mathrm{CO}_{2} \mathrm{Bu}^{\mathrm{t}}$ & 62 \\
\hline $6 \mathrm{~g}$ & 4-Me- $\mathrm{C}_{6} \mathrm{H}_{4}$ & 4-Me- $\mathrm{C}_{6} \mathrm{H}_{4}-\mathrm{CO}-\left(\mathrm{CH}_{2}\right)_{3}-\mathrm{CO}_{2} \mathrm{Me}$ & 75 \\
\hline $6 \mathbf{h}$ & $\mathrm{CH}_{3} \mathrm{C} \equiv \mathrm{C}$ & $\mathrm{Me}-\mathrm{C} \equiv \mathrm{C}-\mathrm{CO}-\left(\mathrm{CH}_{2}\right)_{3}-\mathrm{CO}_{2} \mathrm{Me}$ & 72 \\
\hline $6 \mathbf{i}$ & $n-\mathrm{Bu}$ & $\mathrm{Me}-\left(\mathrm{CH}_{2}\right)_{3}-\mathrm{CO}-\left(\mathrm{CH}_{2}\right)_{6}-\mathrm{CO}_{2} \mathrm{Me}$ & 53 \\
\hline $6 \mathbf{j}$ & $4-\mathrm{Me}-\mathrm{C}_{6} \mathrm{H}_{4}$ & $4-\mathrm{Me}-\mathrm{C}_{6} \mathrm{H}_{4}-\mathrm{CO}-\left(\mathrm{CH}_{2}\right)_{6}-\mathrm{CO}_{2} \mathrm{Me}$ & 74 \\
\hline $6 \mathbf{k}$ & $\mathrm{C}_{6} \mathrm{H}_{5}$ & $\mathrm{C}_{6} \mathrm{H}_{5}-\mathrm{CO}-\left(\mathrm{CH}_{2}\right)_{8}-\mathrm{CO}_{2} \mathrm{Me}$ & 82 \\
\hline 61 & $\mathrm{CH}_{3} \mathrm{C} \equiv \mathrm{C}$ & $\mathrm{Me}-\mathrm{C} \equiv \mathrm{C}-\mathrm{CO}-\left(\mathrm{CH}_{2}\right)_{8}-\mathrm{CO}_{2} \mathrm{Me}$ & 62 \\
\hline
\end{tabular}

Yields refer to product after purification. All the products were identified by comparison with authentic samples or by fully spectroscopical data and literature data.

Appart from the restriction stated for 3-oxo esters, the method was generally applicable to the synthesis of methyl and $t$-butyl 4-oxo and homologous esters. Representative results obtained with alkyl, aryl and alkynyl Grignard reagents are shown in Table 1.

The alkoxycarbonylalkyl imidazolium salts $5^{10}$ were prepared by reacting alkoxycarbonylalkyl acyl chlorides or alkoxycarbonylalkyl carboxylic acids with 3-methyl-1-methylaminoimidazolium iodide as previously reported for 1-3 $^{\text {s-7 }}$ In a typical procedure the oxo esters were prepared as follows: to a solution of the salt $(0.5 \mathrm{mmol})$ in THF at $-10^{\circ} \mathrm{C}$, LDA $(0.55 \mathrm{mmol}, 2 \mathrm{M}$ solution in THF) was added dropwise and the resulting reaction mixture was stirred for $30 \mathrm{~min}$. The corresponding Grignard reagent $(0.55 \mathrm{mmol})$ was added and the mixture was allowed to warm to room temperature. The reaction mixture was quenched with $1 \mathrm{~mL}$ of $\mathrm{HCl}(5 \%)$ and partitioned between a 1:1 mixture of water and diethyl ether $(20 \mathrm{~mL})$. The aqueous layer was extracted with diethyl ether $(3 \times 10 \mathrm{~mL})$ and the combined organic extracts were dried over $\mathrm{Na}_{2} \mathrm{SO}_{4}$ and concentrated under reduced pressure. Purification of the crude product by column chromatography gave the pure oxo ester.

In conclusion, the use of the new $\mathrm{N}$-acylimidazolium derivatives $\mathbf{5}$, following the outlined strategy, provides an easy and efficient method for the preparation of a variety of 4-oxo and homologous esters. The synthesis of 3-oxo esters from the corresponding imidazolium amides is still not practical and efforts to achieve this goal are under way. 
Acknowledgment. The authors acknowledge the Comisió Interdepartamental de Recerça i Innovació Técnologica (CIRIT, project QFN94-4619) for financial support, and the Ministerio de Educación y Ciencia for a studentship (M.A.H.).

\section{REFERENCES}

1. For reviews, see: (a) Shirley, D. A. Org. React. 1954, 8, 28. (b) Jorgenson, M. J. Org. React. 1970, $18,1$.

2. O'Neill, B. T. In Comprehensive Organic Synthesis, 1991, Vol. 1, p 397.

3. Nahm, S.; Weinreb, S. M. Tetrahedron Lett. 1981, 56, 291.

4. For recent applications, see: (a) Sibi, M. P. Org. Prep. Proced. Int. 1993, 25, 15. (b) Evans, D. A.; GauchetPrunet, J. A. J. Org. Chem. 1993, 58, 2446. (c) Sibi, P. M. Marvin, M.; Sharma., R. J. Org. Chem. 1995, 60, 5016. (d) Sibi, M. P.; Christensen, J. W.; Kim, S.-G.; Eggen, M. J.; Stessman, C.; Oien, L. Tetrahedron Lett. 1995, 36, 6209. (e) Williams, J. M.; Jobson, R. B.; Yasuda, N.; Marchesini, G.; Dolling, U.-H.; Grabowski, J. J. Tetrahedron Lett. 1995, 36, 5461. (f) Sawamura, M.; Hamashima, H.; Shinoto, H.; Ito, Y. Tetrahedron Lett. 1995, 36, 64479. (g) Davies, S. G.; McCarthy, T. D. Synlett. 1995, 700. (h) Braslau, R.; Naik, N.; Olmstead, M. M. J. Org. Chem. 1996, 61, 368.

5. Heras, M. A.; Molina, A.; Vaquero, J. J.; García-Navio, J. L.; Alvarez-Builla, J. J. Org. Chem. 1993, 58, 5862 .

6. Heras, M. A.; Vaquero, J. J.; Garcia-Navio, J. L.; Alvarez-Builla, J. Tetrahedron, 1996, 52, 14297.

7. Heras, M. A.; Vaquero, J. J.; García-Navio, J. L.; Alvarez-Builla, J. J. Org. Chem. 1996, 61, 9009.

8. Chiu, C. C.; Jordan, F. J. Org. Chem. 1994, 59, 5763.

9. On quenching the metalated intermediate with $\mathrm{D}_{2} \mathrm{O}$ extensive deuteration of the $\mathrm{C}-2$ imidazolium position occurred.

10. 1-/(3-Methoxycarbonylpropionyl)methylamino]-3-methyl-1H-imidazol-1-ium iodide. White prisms; mp: $128-129^{\circ} \mathrm{C} . \mathbb{R}(\mathrm{KBr}) 3113,3084,3036,1739,1694,1581,1472,1441,1367,1229,1172,1116 \mathrm{~cm}^{-1}$, ${ }^{1} \mathrm{H}-\mathrm{NMR}$ (DMSO-d $\left.\mathrm{d}_{6}, 300 \mathrm{MHz}\right) \delta 10.08$ (bs, $1 \mathrm{H}$ ), 7.54 (bs, $1 \mathrm{H}$ ), 7.45 (bs, $1 \mathrm{H}$ ), 4.16 (s, 3H), 3.77 (bs, 3 H), $3.68(\mathrm{~s}, 3 \mathrm{H}), 2.73-2.75(\mathrm{~m}, 4 \mathrm{H}) \mathrm{ppm}$. Anal. Calc. for $\mathrm{C}_{10} \mathrm{H}_{16} \mathrm{IN}_{3} \mathrm{O}_{3}: \mathrm{C}, 34.01 ; \mathrm{H}, 4.57 ; \mathrm{N}, 11.90$. Found: C, $33.80 ; \mathrm{H}, 4.84 ; \mathrm{N}, 11.77$.

(Received in UK 5 December 1996; revised 22 January 1997; accepted 24 January 1997) 